\title{
Evidence-Based Recommendations for the Oral Health of Patients with Parkinson's Disease
}

\author{
Ana L. C. Martimbianco - Fabio C. Prosdocimi - Camillo Anauate-Netto · \\ Elaine M. dos Santos • Gustavo D. Mendes · Yara D. Fragoso (D)
}

Received: January 14, 2021 / Accepted: February 24, 2021 / Published online: March 18, 2021

(C) The Author(s) 2021

\begin{abstract}
Introduction: Patients with Parkinson's disease (PD) present a variety of oral disease that can be worsened by xerostomia and sialorrhea. The patients' physical limitations, for example rigidity and tremor, add to the difficulty of oral care by the general dental surgeon. The objective of the present review was to organize a list of evidence-based recommendations for the oral care of patients with PD.

Methods: A systematic review of the literature was carried out by specialists who selected the relevant papers and created a list of recommendations based upon the literature.

Results: Fourteen papers (data reported in 16 articles) were included in this review. Patients with PD had reduced quality of oral health and hygiene, and high prevalence of gingival recession, periodontal disease, dental calculus, tooth decay, tooth mobility and loss, drooling, xerostomia, dysphagia and temporomandibular
\end{abstract}

Supplementary Information The online version contains supplementary material available at https:// doi.org/10.1007/s40120-021-00237-4.

A. L. C. Martimbianco - F. C. Prosdocimi

C. Anauate-Netto - E. M. dos Santos .

G. D. Mendes · Y. D. Fragoso ( $\square)$

Postgraduation Department, Program on Health and

Environment, Universidade Metropolitana de

Santos (UNIMES), Santos, SP, Brazil

e-mail: yara@bsnet.com.br disorders. Most studies offered class IV evidence, while one paper had class II evidence.

Conclusion: Patients with PD present poor oral health with conditions that are mostly preventable.

Keywords: Dentistry; Movement disorders; Neurology; Oral health; Parkinson

\section{Key Summary Points}

Patients with Parkinson's disease (PD) present a variety of oral disease that can be worsened by xerostomia and sialorrhea.

A systematic review of the literature was carried out and a list of recommendations has been created.

Patients with PD present poor oral health with conditions that are mostly preventable.

Routine consultations with dental surgeons may improve the quality of life of patients with PD. 


\section{DIGITAL FEATURES}

This article is published with digital features, including a summary slide, to facilitate understanding of the article. To view digital features for this article go to https://doi.org/10.6084/ m9.figshare.14096261.

\section{INTRODUCTION}

Parkinson's Disease (PD) is one of the most frequent neurodegenerative diseases, characterized by motor, autonomic, cognitive and behavioral symptoms [1]. Patients with PD will live with this condition from its onset until death, undergoing a variety of pharmacological and/or non-pharmacological treatments. At disease onset, often concerned with mobility limitations, the patient and the physician will focus on this aspect of the disease. Subsequently, cognitive and behavioral symptoms may add to the disease burden, while superimposed autonomic dysfunction makes PD management particularly challenging [2]. Faced with these myriad disabling symptoms, it is not unexpected that oral health may become a secondary aspect of the patients' lives.

The interdisciplinary approach to patients with PD is highly recommended, but it is not common to have a dentist in the group [3]. Oral care of these patients is often neglected by the patients and their caregivers and physicians [4]. Some diseases reported in patients with PD include increased prevalence of caries and periodontal disease, sialorrhea and drooling, xerostomia, orofacial pain, bruxism and taste impairment [4]. The physiopathology of oral disorders in patients with PD is complex and is not fully understood. Drooling, for example, can be caused by dopamine-induced increased speed of salivary excretion, increased salivary flow rate swallowing dysfunction, hypomimia, lingual bradykinesia and abnormal flexed posture in a patient with reduced salivary production [5]. Although the association between xerostomia and drooling may seem paradoxical, in PD these two conditions may often occur together [5]. In addition, chronic oral inflammation by Porphyromonas gingivalis, a keystone pathogen in periodontitis, causes microbial dysbiosis typical of the neuroinflammation [6]. Periodontal disease has been considered a feature of PD due to poor motor and cognitive control, leading to poor oral health maintenance $[7,8]$. However, the association between the two conditions may be two-sided. Chronic neuroinflammation is consistently associated with the pathophysiology of PD and is one of the contributing factors for neurodegeneration [8]. P. gingivalis may be associated with the development of PD and may be more frequent in patients with periodontal disease [7].

The objective of the present study was to review different aspects of oral health in PD and to establish evidence-based recommendations for the prevention and treatment of oral cavity diseases.

\section{METHODS}

\section{Eligibility Criteria for Including Studies}

Clinical trials and observational studies assessing different aspects of oral health among patients with PD were included in this review. These involved associations between different aspects of PD and oral cavity diseases, along with any type of treatment or preventive strategies. Case reports, reviews, guidelines and experimental studies were excluded. This article is based on previously conducted studies and does not contain any new studies with human participants or animals performed by any of the authors.

\section{Search Strategies for Identifying Studies}

A comprehensive and sensitive search was conducted first on 24 March 2020 and then updated on 23 November 2020, in the following electronic databases: MEDLINE (via PubMed), Embase (via Elsevier), Cochrane Central Register of Controlled Trials (CENTRAL), Latin American \& Caribbean Health Sciences Literature (LILACS) (via Biblioteca Virtual em Saúde, BVS) and Brazilian Bibliography of Odontology (BBO) (via BVS). We also hand-searched the 
reference lists of relevant studies to identify any potentially eligible study. The full search strategies are presented in Supplementary File 1. There were no language or date restrictions.

\section{Selection of Studies and Data Extraction}

Two authors independently reviewed the title and abstracts recovered through the search using the Rayyan platform [3]. References identified as "potentially eligible" were analyzed in full text. Any disagreement was resolved by a third reviewer.

Data extraction from the studies included was performed by four independent reviewers using a pre-established data extraction form. The data gathered comprised the main characteristics of the studies included (study design, sample size, participant characteristics, intervention and comparator groups, outcomes assessed, follow-up and results). Any disagreement was resolved by two other review authors.

\section{Data Synthesis}

The results from the studies included were presented narratively in accordance with the hierarchy of evidence levels [4].

\section{RESULTS}

Through the search strategies, a total of 121 references were retrieved. After removed 17 duplicates, 104 were screened using their titles and abstracts, and out of these, 41 potentially eligible references were analyzed in full text. Twenty-two studies did not meet the inclusion criteria and were excluded (reviews and case reports). Two other studies were excluded because they dealt with oral-related risk factors associated with the development of PD in previously healthy individuals. One study was excluded because it only discussed the reduction in the risk of developing PD when an individual underwent dental scaling [5]. This study compared two populations: 4765 adults with PD and 19,060 age-matched individuals without PD. Another study [6] investigated data from 20,175 individuals who were free from PD in 1973 and 1974, regarding the evolution of their health up to 2012. Among men, use of tobacco was associated with a lower risk of developing PD, but their number of teeth and the presence of plaque were not associated with having PD after 28 years of follow-up.

Thus, 14 studies (reported in 16 papers) were included in this review [7-22]. Figure 1 shows the study selection process. Table 1 shows a summary of the data retrieved from the 16 articles that were included in the systematic review, along with the level of evidence for each of them. In summary, the studies pointed out that patients with PD had reduced quality of oral health and hygiene. Presence of PD was associated with gingival recession, periodontal disease, dental calculus, tooth decay, tooth mobility and loss, drooling, xerostomia, dysphagia and temporomandibular disorders. Except for one study with class II evidence [7], all the papers had class IV evidence.

\section{DISCUSSION}

There is no question that oral health is important for everyone. Although oral diseases are largely preventable, they are among the most prevalent diseases globally, thus creating a public health problem [23].

Despite the relatively low level of evidence in studies on oral health among patients with PD, the data retrieved for this systematic review allowed us to create a set of simple guidelines. We thus created a list of practical, evidencebased recommendations for all neurologists and dentists who treat patients with PD.

\section{General Dental Care}

o During neurological consultations, the physician needs to introduce the issue of visits to a dentist.

$\mathrm{p}$ Should the patient not have regular dental appointments, the neurologist should refer this individual to an oral health care center.

$\mathrm{q}$ Teeth brushing needs to be done regularly and should be performed alternating the right and the left hands, since rigidity and 


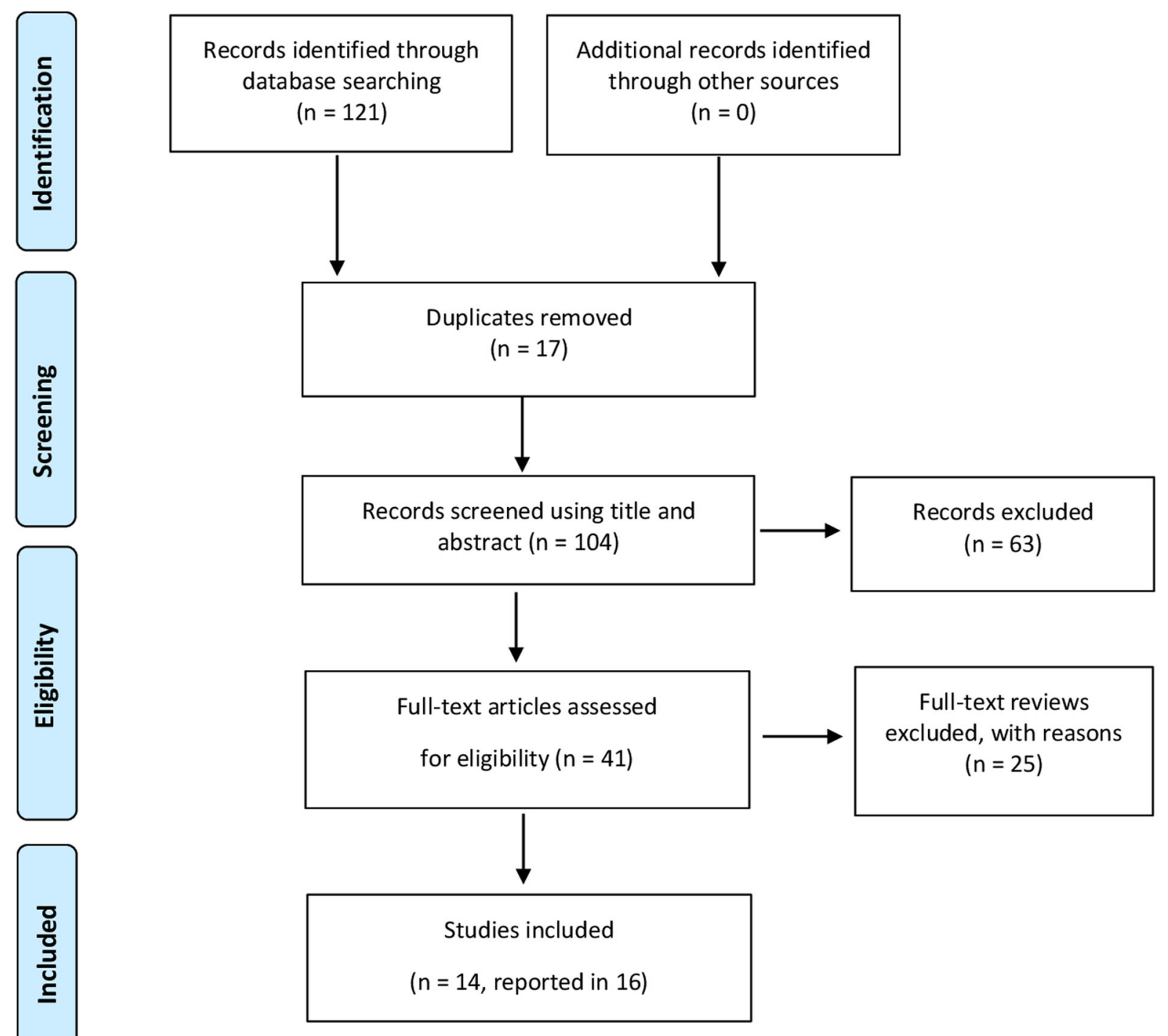

Fig. 1 Flowchart of article selection for the systematic review

tremor may be more disabling in one limb as PD progresses. Therefore, the patient should learn to use either hand for oral hygiene.

$\mathrm{r}$ Individualized instructions regarding oral hygiene, together with chewing and lip exercises, can improve oral health in PD cases [7].

\section{Salivation}

o PD is associated with hyposalivation or xerostomia (autonomic and anticholinergic drugs), drooling (motor or dysphagia) and halitosis. [11-13, 16]. The neurologist and the dentist should assess these conditions and establish the best possible approach to control them.

p Low salivary flow can be relieved through artificial saliva spray [24].

$\mathrm{q}$ Botulinum toxin applied to the parotid and submandibular glands can relieve drooling [25]. However, this procedure may increase xerostomia, and the risk/benefit ratio must be assessed carefully (Fuster Torres et al. [26]). 
Table 1 Summary of the studies included in the systematic review

\begin{tabular}{|c|c|c|c|c|}
\hline $\begin{array}{l}\text { Author/ } \\
\text { year/country }\end{array}$ & $\begin{array}{l}\text { Study } \\
\text { design/level } \\
\text { of evidence }\end{array}$ & Participants & Interventions/exposure & Results \\
\hline $\begin{array}{l}\text { Baram et al. } \\
\text { [7] } \\
\text { Denmark }\end{array}$ & $\begin{array}{l}\text { RCT } \\
\text { Level II }\end{array}$ & $\begin{array}{l}n=29 \\
\text { Median } \\
65 \text { years } \\
\text { Moderate to } \\
\text { advanced } \\
\text { PD }\end{array}$ & $\begin{array}{l}\text { G1: Individual dental hygiene } \\
\text { instruction, training of jaw } \\
\text { opening, and lip and chewing } \\
\text { exercises }(\mathrm{n}=15) \\
\text { G2: Only instructions } \\
(\mathrm{n}=14)\end{array}$ & $\begin{array}{l}\text { G1 patients improved jaw opening, } \\
\text { chewing time and hygiene after } \\
2 \text { months } \\
\text { No significant changes were found } \\
\text { among G2 patients after } 2 \text { months }\end{array}$ \\
\hline $\begin{array}{l}\text { Zarpelon } \\
\text { et al. [8] } \\
\text { Brazil }\end{array}$ & $\begin{array}{l}\text { Cross- } \\
\text { sectional } \\
\text { Level IV }\end{array}$ & $\begin{array}{l}n=50 \\
\text { Aged } \\
53-94 \text { years } \\
\text { Mild PD }\end{array}$ & $\begin{array}{l}\text { Oral cavity examination to assess } \\
\text { prosthetic use and need; index of } \\
\text { DMFT; CPI; PAL; and oral } \\
\text { mucosa }\end{array}$ & $\begin{array}{l}92 \% \text { prosthetic use in upper arch } \\
66 \% \text { prosthetic need in lower arch } \\
43 \% \text { missing teeth (DMFT) } \\
43 \% \text { dental calculus (CPI) } \\
28 \% \text { attachment loss (PAL) } \\
\text { Findings in oral mucosa: denture } \\
\text { stomatitis, inflammatory fibrous } \\
\text { hyperplasia }\end{array}$ \\
\hline $\begin{array}{l}\text { Silva et al. } \\
\qquad[9] \\
\text { Brazil }\end{array}$ & $\begin{array}{l}\text { Cross- } \\
\text { sectional } \\
\text { Level IV }\end{array}$ & $\begin{array}{l}n=59 \\
\text { Age } \\
50-75 \text { years } \\
83 \% \text { mild } \\
\text { PD }\end{array}$ & $\begin{array}{l}\text { Signs and symptoms of TMD with } \\
\text { RDC/TMD }\end{array}$ & $\begin{array}{l}\text { Prevalence of TMD } 20.3 \%(\mathrm{n}=12) \\
\text { More frequent among women } \\
(\mathrm{n}=7) \\
\text { No significant association between } \\
\text { TMD and PD severity }\end{array}$ \\
\hline $\begin{array}{l}\text { van Stiphout } \\
\text { et al. [10] } \\
\text { Netherlands }\end{array}$ & $\begin{array}{l}\text { Case-control } \\
\text { Level IV }\end{array}$ & $\begin{array}{l}n=74 \text { with } \\
\text { PD } \\
n=74 \\
\text { without PD } \\
\text { Aged } \\
40-69 \text { years }\end{array}$ & $\begin{array}{l}\text { Oral health status and PD duration } \\
\text { and severity }\end{array}$ & $\begin{array}{l}\text { Patients with PD had weakened oral } \\
\text { health status and reduced oral } \\
\text { hygiene care } \\
\text { PD duration and severity were } \\
\text { associated with poor oral health } \\
\text { and hygiene care problems }\end{array}$ \\
\hline $\begin{array}{l}\text { Tiigimäe- } \\
\text { Saar et al. } \\
{[11]} \\
\text { Estonia }\end{array}$ & $\begin{array}{l}\text { Case-control } \\
\text { Level IV }\end{array}$ & $\begin{array}{l}n=12 \text { with } \\
\text { PD } \\
n=13 \\
\text { without PD } \\
n=13 \\
\text { healthy } \\
\text { subjects } \\
\text { mean age of } \\
71.1 \text { years }\end{array}$ & $\begin{array}{l}\text { Botulinum toxin type A for } \\
\text { sialorrhea (bilateral parotid and } \\
\text { submandibular glands) }\end{array}$ & $\begin{array}{l}\text { Decrease in salivary flow at } 1 \text { month } \\
\text { No changes in salivary composition } \\
\text { Increased levels of Lactobacilli count, } \\
\text { which can have a negative effect on } \\
\text { PD } \\
\text { No adverse events observed }\end{array}$ \\
\hline
\end{tabular}


Table 1 continued

\begin{tabular}{|c|c|c|c|c|}
\hline $\begin{array}{l}\text { Author/ } \\
\text { year/country }\end{array}$ & $\begin{array}{l}\text { Study } \\
\text { design/level } \\
\text { of evidence }\end{array}$ & Participants & Interventions/exposure & Results \\
\hline $\begin{array}{l}\text { Barbe et al. } \\
\quad[12,13] \\
\text { Germany }\end{array}$ & $\begin{array}{l}\text { Case-control } \\
\text { Level IV }\end{array}$ & $\begin{array}{l}\mathrm{n}=26 \text { with } \\
\mathrm{PD} \\
\mathrm{n}=26 \\
\text { without PD } \\
\text { Mean age } \\
69 \text { years }\end{array}$ & Halitosis and PD & $\begin{array}{l}\text { More patients with PD perceived } \\
\text { halitosis to be stronger ( } 77 \% \text { vs. } \\
54 \%) \\
\text { Dry mouth was more frequent } \\
\text { among PD patients } \\
\text { OHRQoL lower among patients } \\
\text { with PD } \\
\text { Patients with PD had more } \\
\text { hyposalivation ( } 87 \% \text { vs. } 50 \%) \\
50 \% \text { reported xerostomia, vs. none o } \\
\text { controls }\end{array}$ \\
\hline $\begin{array}{l}\text { Ribeiro et al. } \\
\qquad[14,15] \\
\text { Brazil }\end{array}$ & $\begin{array}{l}\text { Case-control } \\
\text { Level IV }\end{array}$ & $\begin{array}{l}n=17 \text { with } \\
\text { PD } \\
n=17 \\
\text { without PD } \\
\text { Mean age } \\
69.4 \text { years }\end{array}$ & $\begin{array}{l}\text { Oral rehabilitation with a removable } \\
\text { prosthesis and PD }\end{array}$ & $\begin{array}{l}\text { Improved OHRQoL and } \\
\text { masticatory efficiency } 2 \text { months } \\
\text { after intervention in both groups } \\
\text { No group differences in the number } \\
\text { of remaining teeth, DMFT, VPI or } \\
\text { salivary flow rate } \\
\text { Lower GOHAI scores among } \\
\text { patients with PD } \\
\text { Patients with PD had more negative } \\
\text { self-perceptions of their oral health }\end{array}$ \\
\hline $\begin{array}{l}\text { Barbe et al. } \\
\qquad 16] \\
\text { Germany }\end{array}$ & $\begin{array}{l}\text { Cross- } \\
\text { sectional } \\
\text { Level IV }\end{array}$ & $\begin{array}{l}n=100 \\
\text { Mean age } \\
71 \text { years }\end{array}$ & $\begin{array}{l}\text { Self-assessed dental care: ability to } \\
\text { perform oral hygiene, self-assessed } \\
\text { xerostomia, drooling and } \\
\text { dysphagia problems, and the } \\
\text { impact on OHRQoL }\end{array}$ & $\begin{array}{l}49 \% \text { xerostomia, } 70 \% \text { drooling and } \\
47 \% \text { dysphagia } \\
29 \% \text { with limited ability to perform } \\
\text { oral hygiene } \\
\text { Xerostomia, drooling, and dysphagia } \\
\text { impaired the OHRQoL } \\
6.1 \% \text { of participants with xerostomia } \\
\text { received advice regarding } \\
\text { management }\end{array}$ \\
\hline $\begin{array}{l}\text { Bonenfant } \\
\text { et al. [17] }\end{array}$ & $\begin{array}{l}\text { Cross- } \\
\text { sectional }\end{array}$ & $\begin{array}{l}n=203 \\
\text { Mean age }\end{array}$ & $\begin{array}{l}\text { Frequency of BMS among PD } \\
\text { patients }\end{array}$ & $\begin{array}{l}\text { Low prevalence of BMS among } \\
\text { patients with PD }(4 \%)\end{array}$ \\
\hline $\begin{array}{r}\text { Canada/ } \\
\text { France }\end{array}$ & Level IV & 68.2 years & & $\begin{array}{l}\text { Poor oral health index was higher } \\
\text { with BMS than without BMS }\end{array}$ \\
\hline
\end{tabular}


Table 1 continued

\begin{tabular}{|c|c|c|c|c|}
\hline $\begin{array}{l}\text { Author/ } \\
\text { year/country }\end{array}$ & $\begin{array}{l}\text { Study } \\
\text { design/level } \\
\text { of evidence }\end{array}$ & Participants & Interventions/exposure & Results \\
\hline
\end{tabular}

Pradeep et al. Case-control $n=45$ with Periodontal status and severity of PD All the periodontal clinical

[18] Level IV PD

India

$n=46$

without PD

parameters and indices evaluated

deteriorated with increasing

Mean age

58.7 years

Cicciù et al. Case-control $n=45$ with Periodontal status and severity of PD

Level IV PD

Italy

$n=45$

without PD

Mean age

65 years

Müller et al. Case-control $n=101 \quad$ Oral health and PD

[20] Level IV with PD

Germany $n=75$

without PD

Mean age

66.2 years

Bakke et al. Case-control $n=15$ with Orofacial function and oral health

Level IV

PD

among PD patients

Denmark

$$
\begin{aligned}
& n=15 \\
& \text { without PD } \\
& \text { Aged } \\
& \text { 62-81 years }
\end{aligned}
$$

$\begin{array}{cccc}\begin{array}{c}\text { Packer et al. } \\ {[22]}\end{array} & \text { Cross- } & n=9 \text { with } & \text { QoL of patients with PD with } \\ \text { United } & \text { sectional } & \text { PD } & \text { implants } \\ \text { Kingdom } & \text { All men IV } & \text { Aged } \\ & 54-77 \text { years }\end{array}$

Higher frequency of untreated caries, periodontal diseases and missing teeth among patients with PD

Patients with PD had poorer oral health (papilla bleeding index), gingival recession and tooth mobility, lower frequency of teeth brushing, longer time since the last dentist visit and reduced salivary flow

Patients with PD had more prevalent orofacial dysfunction, poorer mastication and jaw opening and negative impact of oral health on daily life

Dental implants had $82 \%$ success rate and improved both oral and general QoL among patients with SD

$R C T$ randomized clinical trial, $n$ number of participants, $P D$ Parkinson's disease, $G$ group, DMFT decayed, missing and filled teeth, $C P I$ Community Periodontal Index, $P A L$ periodontal attachment loss, TMD temporomandibular disorder, RDC/TMD Research Diagnostic Criteria for Temporomandibular Disorders, PID periodontal inflammatory disease, $O H R Q O L$ oral health-related quality of life, $V P I$ visible plaque index, GOHAI General Oral Health Assessment Index, BMS burning mouth syndrome, $Q o L$ quality of life 
r Photodynamic therapy on the tongue surface may be a good option for halitosis [27].

\section{Tooth Decay and Loss}

o Patients with PD have a higher frequency of untreated caries $[19,20]$. This can be corrected through regular dental appointments.

$\mathrm{p}$ Tooth loss can be successfully corrected through osseointegrated implants, as shown in nine patients with PD and tooth loss in an open, uncontrolled study [22]. Partial and complete prostheses have also been presented as an alternative to tooth loss $[14,15,28]$. However, it needs to be kept in mind that placing dentures and keeping them functional may be a burden for patients with tremor, rigidity, xerostomia and drooling. In addition, denture stomatitis and inflammatory fibrous hyperplasia have been reported in patients with PD using dentures [8]. Therefore, whenever possible, osseointegrated implants are recommended.

\section{Periodontal Disease}

o PD is associated with gingival recession and bleeding, plaques, dental calculus and tooth mobility $[8,18-20]$. Improved hygiene may ultimately lead to lower rates of periodontal disease and, consequently, less tooth loss. Regular visits to a periodontist should be encouraged.

\section{Temporomandibular Disorder (TMD)}

o Patients with PD showed a higher prevalence of TMD, particularly women $[9,21]$. While around $20 \%$ of patients with PD show signs and symptoms of TMD, the elderly population generally has a $12 \%$ prevalence of temporomandibular dysfunction [29]. Less than $4 \%$ of elderly subjects have severe TMD [30].

$\mathrm{p}$ Untreated TMD may add to the burden of $\mathrm{PD}$, by generating greater pain and orofacial dysfunction. TMD needs to be investigated and treated.

\section{Burning Mouth Syndrome (BMS)}

o Although the prevalence of BMS is not higher than $4 \%$ among patients with PD, this condition has been correlated with poor oral conditions [17]. Therefore, to avoid adding a burden of BMS to individuals already presenting with disability, good oral health needs to be maintained among patients with PD.

\section{CONCLUSIONS}

Patients with PD have a variety of oral diseases that needs to be prevented, diagnosed and treated. The present paper provides a list of evidence-based recommendations for neurologists and dentists caring for these patients.

\section{ACKNOWLEDGEMENTS}

Funding. No funding or sponsorship was received for this study or publication of this article.

Authorship. All named authors meet the International Committee of Medical Journal Editors (ICMJE) criteria for authorship for this article, take responsibility for the integrity of the work as a whole, and have given their approval for this version to be published.

Disclosures. The authors Ana Luiza Cabrera Martimbianco, Fabio Cesar Prosdocimi, Camillo Anauate-Netto, Elaine Marcílio dos Santos, Gustavo Duarte Mendes and Yara Dadalti Fragoso have no conflicts of interest to declare. Yara Dadalti Fragoso is a member of the journal's Editorial Board.

Compliance with Ethics Guidelines. This article is based on previously conducted studies and does not contain any new studies with 
human participants or animals performed by any of the authors.

Data Availability. Data sharing is not applicable to this article as no data sets were generated or analyzed during the current study.

Open Access. This article is licensed under a Creative Commons Attribution-NonCommercial 4.0 International License, which permits any non-commercial use, sharing, adaptation, distribution and reproduction in any medium or format, as long as you give appropriate credit to the original author(s) and the source, provide a link to the Creative Commons licence, and indicate if changes were made. The images or other third party material in this article are included in the article's Creative Commons licence, unless indicated otherwise in a credit line to the material. If material is not included in the article's Creative Commons licence and your intended use is not permitted by statutory regulation or exceeds the permitted use, you will need to obtain permission directly from the copyright holder. To view a copy of this licence, visit http://creativecommons.org/licenses/by$\mathrm{nc} / 4.0 /$.

\section{REFERENCES}

1. Armstrong MJ, Okun MS. Diagnosis and treatment of Parkinson disease: a review. JAMA. 2020;323(6): 548-60. https://doi.org/10.1001/jama.2019.22360.

2. Reich SG, Savitt JM. Parkinson's disease. Med Clin N Am. 2019;103(2):337-50. https://doi.org/10. 1016/j.mcna.2018.10.014.

3. Ouzzani M, Hammady H, Fedorowicz Z, Elmagarmid A. Rayyan - a web and mobile app for systematic reviews. Syst Rev [Internet]. 2016;5(1):210.

4. - OCEBM Levels of Evidence Working Group*. "The Oxford Levels of Evidence 2". Oxford Centre for Evidence-Based Medicine. https://www.cebm.ox.ac. uk/resources/levels-of-evidence/ocebm-levels-ofevidence. (Accessed on Nov 26, 2020).

5. Chen CK, Huang JY, Wu YT, Chang YC. Dental scaling decreases the risk of Parkinson's disease: a nationwide population-based nested case-control study. Int J Environ Res Public Health. 2018;15(8): 1587. https://doi.org/10.3390/ijerph15081587.

6. Liu Z, Roosaar A, Axéll T, Ye W. Tobacco use, oral health, and risk of Parkinson's disease. Am J Epidemiol. 2017;185(7):538-45. https://doi.org/10. 1093/aje/kww146.

7. Baram S, Karlsborg M, Bakke M. Improvement of oral function and hygiene in Parkinson's disease: a randomised controlled clinical trial. J Oral Rehabil. 2020;47(3):370-6. https://doi.org/10.1111/joor. 12924.

8. Zarpelon C, Regina Stahl Melchiors N, Adalberto Rodrigues-Junior S, da Silva Corralo V, Gassen Kellermann M. Oral health condition of elderly people with Parkinson disease. RFO UPF. 2019;24(2):211-9 (maio/ago. 2).

9. Silva PF, Biasotto-Gonzalez DA, Motta LJ, Silva SM, Ferrari RA, Fernandes KP, Bussadori SK. Impact in oral health and the prevalence of temporomandibular disorder in individuals with Parkinson's disease. J Phys Ther Sci. 2015;27(3):887-91. https://doi.org/10.1589/jpts.27.887.

10. van Stiphout MAE, Marinus J, van Hilten JJ, Lobbezoo F, de Baat C. Oral health of Parkinson's disease patients: a case-control study. Parkinsons Dis. 2018;8(2018):9315285. https://doi.org/10. $1155 / 2018 / 9315285$.

11. Tiigimäe-Saar J, Tamme T, Rosenthal M, KadastikEerme L, Taba P. Saliva changes in Parkinson's disease patients after injection of Botulinum neurotoxin type A. Neurol Sci. 2018;39(5):871-7. https:// doi.org/10.1007/s10072-018-3279-4.

12. Barbe AG, Bock N, Derman SH, Felsch M, Timmermann L, Noack MJ. Self-assessment of oral health, dental health care and oral health-related quality of life among Parkinson's disease patients. Gerodontology. 2017;34(1):135-43. https://doi.org/10.1111/ ger. 12237.

13. Barbe AG, Deutscher DHC, Derman SHM, Hellmich M, Noack MJ. Subjective and objective halitosis among patients with Parkinson's disease. Gerodontology. 2017;34(4):460-8. https://doi.org/ 10.1111/ger.12293.

14. Ribeiro GR, Campos $\mathrm{CH}$, Garcia RC. Oral health in elders with Parkinson's disease. Braz Dent J. 2016;27(3):340-4. https://doi.org/10.1590/01036440201600881 .

15. Ribeiro GR, Campos $\mathrm{CH}$, Rodrigues Garcia RCM. Influence of a removable prosthesis on oral healthrelated quality of life and mastication in elders with Parkinson disease. J Prosthet Dent. 2017;118(5): 
637-42. https://doi.org/10.1016/j.prosdent.2016. 12.018 .

16. Barbe AG, Heinzler A, Derman S, Hellmich M, Timmermann L, Noack MJ. Hyposalivation and xerostomia among Parkinson's disease patients and its impact on quality of life. Oral Dis. 2017;23(4): 464-70. https://doi.org/10.1111/odi.

17. Pradeep AR, Singh SP, Martande SS, Raju AP, Rustagi T, Suke DK, Naik SB. Clinical evaluation of the periodontal health condition and oral health awareness in Parkinson's disease patients. Gerodontology. 2015;32(2):100-6. https://doi.org/ 10.1111/ger.12055.

18. Cicciù M, Risitano G, Lo Giudice G, Bramanti E. Periodontal health and caries prevalence evaluation in patients affected by Parkinson's disease. Parkinsons Dis. 2012;2012:541908. https://doi.org/10. $1155 / 2012 / 541908$.

19. Müller T, Palluch R, Jackowski J. Caries and periodontal disease in patients with Parkinson's disease. Spec Care Dentist. 2011;31(5):178-81. https://doi. org/10.1111/j.1754-4505.2011.00205.x.

20. Bakke M, Larsen SL, Lautrup C, Karlsborg M. Orofacial function and oral health in patients with Parkinson's disease. Eur J Oral Sci. 2011;119(1): 27-32. https://doi.org/10.1111/j.1600-0722.2010. 00802.x.

21. Packer ME. Are dental implants the answer to tooth loss in patients with Parkinson's disease? Prim Dent J. 2015;4(2):35-41. https://doi.org/10.1308/ 205016815814955091.

22. Peres MA, Macpherson LMD, Weyant RJ, Daly B, Venturelli R, Mathur MR, Listl S, Celeste RK, Guarnizo-Herreño CC, Kearns C, Benzian H, Allison P, Watt RG. Oral diseases: a global public health challenge. Lancet. 2019;394(10194):249-60. https://doi.org/10.1016/S0140-6736(19)31146-8.
23. Spirk C, Hartl S, Pritz E, Gugatschka M, Kolb-Lenz D, Leitinger G, Roblegg E. Comprehensive investigation of saliva replacement liquids for the treatment of xerostomia. Int J Pharm. 2019;25(571): 118759. https://doi.org/10.1016/j.ijpharm.2019. 118759.

24. Jocson A, Lew M. Use of botulinum toxin in Parkinson's disease. Parkinsonism Relat Disord. 2019;59:57-64. parkreldis.2018.12.002.

25. Javed F. Halitosis and photodynamic therapy. Photodiagnosis Photodyn Ther. 2020;17:102006. https://doi.org/10.1016/j.pdpdt.2020.102006.

26. Fuster Torres MA, Berini Aytés L, Gay Escoda C. Salivary gland application of botulinum toxin for the treatment of sialorrhea. Med Oral Patol Oral Cir Bucal. 2007;12(7):E511-7.

27. Farrow-Hamblen A. Prostheses in Parkinson's disease. Br Dent J. 2019;227(5):329. https://doi.org/10. 1038/s41415-019-0759-8.

28. Carlsson GE, Ekbäck G, Johansson A, Ordell S, Unell L. Is there a trend of decreasing prevalence of TMDrelated symptoms with ageing among the elderly? Acta Odontol Scand. 2014;72(8):714-20. https:// doi.org/10.3109/00016357.2014.898787.

29. Unell L, Johansson A, Ekbäck G, Ordell S, Carlsson GE. Prevalence of troublesome symptoms related to temporomandibular disorders and awareness of bruxism in 65- and 75-year-old subjects. Gerodontology. 2012;29(2):e772-9. https://doi.org/10.1111/ j.1741-2358.2011.00558.x.

30. Yadav S, Yang Y, Dutra EH, Robinson JL, Wadhwa S. Temporomandibular joint disorders in older adults. J Am Geriatr Soc. 2018;66(6):1213-7. https://doi. org/10.1111/jgs.15354. 